\title{
PENGEMBANGAN MODEL PEMBELAJARAN MY TRIP MY ADVENTURE
}

\author{
Dedy Febry Rachman ${ }^{1}$, Restu Fahdiansyah ${ }^{2}$ \\ UNIVERSITAS BUMIGORA \\ dedyfebry18@gmail.com ${ }^{1}$ \\ restusyah@gmail.com²
}

\begin{abstract}
Abstrak - Tujuan penelitian pengembangan ini diharapkan akan menghasilkan suatu paket produk pengembangan berupa model pembelajaran: 1). Perangkat pembelajaran, 2). Pedoman penilaian/evaluasi pembelajaran, 3). Pedoman untuk pengembangan pembelajaran, 4). Menghasilkan model pembelajaran berbasis game yang di adopsi dari monopoli, 5). Pengembangan model didasarkan pada identifikasi karakteristik siswa pada usianya yang telah mencapai tahap operasional formal dari sisi perkembangan kognitif, 6). Pengembangan model didasarkan pada identikkasi tujuan pembelajaran dengan mempertimbangkan kurikulum yang telah diterapkan yaitu pengembangan materi dari kurikulum 2013, 7). Model pembelajaran fokus pada satu materi saja, dan tidak dapat diterapkan model yang sama untuk materi pelajaran yang lainnya.

Setelah produk selesai dikembangkan selanjutnya dilakukan proses uji validasi ahli, uji coba perorangan, uji kelompok kecil dan uji lapangan. Berdasarkan hasil uji tersebut, model pembelajaran sangat valid, menarik, dan efektif dapat diterapkan dalam pembelajaran. Hal ini dapat diketahui dari hasil uji validasi dengan tingkat kelayakan produk dari ahli isi/materi sebesar $89 \%$, validasi ahli media pembelajaran diperoleh skor rata-rata sebesar $91 \%$.Tingkat kemenarikan produk dengan skor presentase rata-rata sebesar $92,92 \%$ masuk kriteria sangat menarik. Produk efektif digunakan dengan rata-rata skor presentase sebesar $90,76 \%$.

Produk ini juga dapat dimanfaatkan untuk kalangan lebih luas dengan penyesuaian terutama penyesuaian pada karakteristik siswa sebagai pengguna. Lebih lanjut model pembelajaran yang sudah dikembangkan dapat diintegrasikan dengan penggunaan teknologi informasi dan komunikasi.
\end{abstract}

\section{Keywords: Development, Learning Model, My Trip My Adventure}

\section{Latar Belakang}

Sumber daya manusia Indonesia seutuhnya telah dirumuskan dalam GBHN mengenai arah pembangunan jangka panjang. Dinyatakan bahwa pembangunan nasional dilaksanakan dalam rangka pembangunan manusia Indonesia seutuhnya dan pembangunan seluruh rakyat Indonesia. Ini menjelaskan pentingnya pendidikan sebagai pengembangan sumber daya manusia untuk memicu pembangunan secara menyeluruh, termasuk pembangunan ekonomi yang dapat dicapai melalui model pembelajaran khusus untuk ekonomi yang bermutu.

Dalam materi yang disampaikan pada seminar pendidikan nasional oleh Wahyono (2013) diungkap fenomena-fenomena yang terkait dengan pendidikan ekonomi yang ada di Indonesia, diantaranya adalah:

“.... (1) Berbagai penelitian yang dilakukan terhadap siswa jenjang pendidikan menengah, mahasiswa dan bahkan guru ekonomi, membuktikan bahwa literasi ekonomi (pemahaman dasar tentang bagaimana perekonomian bekerja) dan literasi keuangan (pemahaman dasar tentang pemanfaatan uang secara efektif dan efisien), mereka masih rendah; (2) Minat dan semangat menabung dan berinvestasi di kalangan pelaku ekonomi masih memprihatinkan, tidak sebanding dengan semangat dan minat untuk berkonsumsi melalui kredit. Pemahaman dan kesadaran atas opportunity cost untuk memegang uang tunai maupun pemanfaatan uang untuk mengkonsumsi barang/jasa tidak dimilki oleh sebagian besar pelaku ekonom; (3) masih banyak pelaku ekonomi yang mengambil keputusan tanpa mempertimbangkan prinsip-prinsip rasionalitas ekonomi (trade off, opportunity cost, marginalism, dan incentive) yang mengakibatkan tidak efektifnya kegiatan produktif dan tidak efisiennya aktivitas konsumtif pelaku ekonom". 
Kegiatan pembelajaran dipengaruhi oleh banyak faktor yang disebut dengan variabel pembelajaran yakni kondisi, metode dan hasil. Metode atau Model pembelajaran adalah suatu rencana atau pola yang dapat digunakan untuk membentuk kurikulum (rencana pembelajaran jangka panjang), merancang bahan-bahan pembelajarn, dan membimbing pembelajaran di kelas atau yang lain.

Berdasarkan perspektif Piaget usia 14-17 tahun telah mempunyai kemampuan kognitif pada tahap pemikiran operasional formal (formal operational thought) dimana dapat berpikir abstrak, sistematis dan sudah dapat melakukan hipotesis tentang masalah-masalah yang dihadapi, maka implementasi model-model pembelajaran yang menarik dan menantang dapat diterapkan pada pembelajaran di kelas untuk memudahkan siswa memahami konsep-konsep ekonomi khususnya pada materi kurs valuta asing.

Model pembelajaran ekonomi My trip my adventure (MTMA) merupakan salah satu solusi yang ditawarkan dalam pengembangan model pembelajaran berbasis simulasi dan game yang diadopsi dari permainan monopoli. Sebagaimana diketahui, bahwa pembelajaran simulasi adalah model pembelajaran yang membuat suatu peniruan terhadap sesuatu yang nyata, terhadap keadaan sekelilingnya atau proses. Model pembelajaran ini dirancang untuk siswa yang mengalami bermacam-macam proses dan kenyataan sosial dan untuk menguji reaksi mereka, serta untuk memperoleh konsep keterampilan pembuatan keputusan yang mempunyai kelebihan yaitu dapat membantu peserta didik untuk memahami faktor-faktor penting dalam kehidupan nyata, apa yang harus dimiliki dan bagaimana cara memiliki agar bisa menjalankan kehidupan (tugas, pekerjaan) pada lingkungan nyata. Dalam implementasi model pembelajaran simulasi membantu peserta didik untuk memainkan peran, membuat keputusan dan menunjukkan konsekuensi.

Dengan demikian, peserta didik akan dilatih untuk mampu membaca, memahami serta menafsirkan permasalahan ekonomi yang ada di sekitarnya, terutama berkaitan dengan kurs valuta asing.

\section{METODE PENELITIAN}

Metode penelitian yang digunakan dalam penelitian ini adalah metode pengembangan, adapun metode pengembangan dirancang dengan menggunakan acuan pada desain pengembangan Borg \& Gall (1989:624), "educational research and development is a process used to develop and validate educational product", Metode penelittian dan pengembangan juga didefinisikan sebagai suatu metode penelitian yang digunakan untuk menghasilkan produk tertentu dan menguji keefektifitasan produk tersebut.

Menurut Borg dan Gall (1989: 783-795), pendekatan research and development (R\&D) meliputi sepuluh tahapan mulai dari (1) research and information collecting; (2) planning; (3)develop preliminary form of product;(4) preliminary field testing; (5)main product revision; (6)mainfield testing; (7)operational productrevision; (8)operational field testing; (9)final product revision; (10)dissemination and implementation.

Tahapan penelitian dan pengembangan tersebut akan digambarkan dalam Gambar 3.1 di bawah ini:

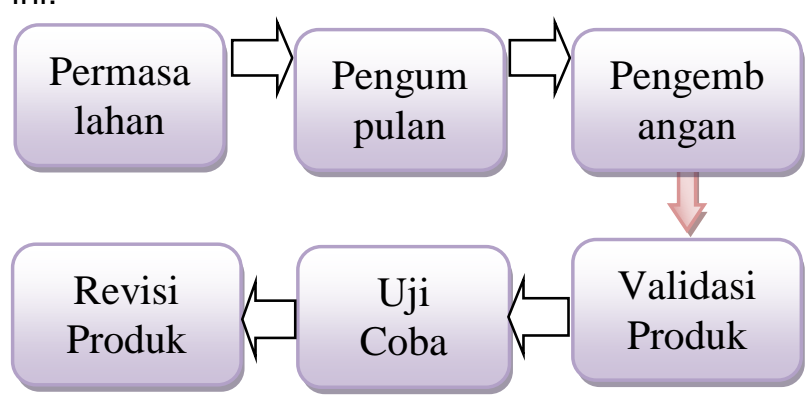

Gambar 3.1 Rancangan penelitian

pengembangan (adaptasi: borg dan gall yang telah di modifikasi)

\section{HASIL DAN LUARAN}

Penyajian data pada penelitian dan pengembangan model pembelajaran secara berurutan adalah tanggapan ahli isi/materi ekonomi, ahli media pembelajaran, uji coba perorangan, uji kelompok kecil dan uji coba lapangan. Data hasil uji coba dipaparkan sebagai berikut:

\section{Data Uji Validasi Ahli Isi/Materi}

Uji ahli isi/materi diperlukan sebagai evaluator terhadap isi/materi yang sudah dikembangkan oleh peneliti. Data yang diperoleh berupa data kuantitatif dan kualitatif melalui lembar validasi yang diberikan peneliti kepada ahli isi/materi.

\begin{tabular}{|l|l|}
\hline No & \multicolumn{1}{|c|}{ Kritik dan Saran } \\
\hline $\mathbf{1}$ & $\begin{array}{l}\text { Model pembelajaran MTMA yang dikembangkan dibuat } \\
\text { alur (bagan) untuk lebih mudah memahami model yang } \\
\text { saudara kembangkan, sehingga mudah dipahami oleh } \\
\text { pembaca } \\
\mathbf{2}\end{array}$ \\
$\begin{array}{l}\text { Ditambahkan lagi istilah-istilah yang belum dipahami di } \\
\text { glosarium }\end{array}$ \\
\hline
\end{tabular}


Peneliti memberikan lembar validasi dan produk awal model pembelajaran kepada Bapak Dr. M. Fahrurrozi, MM. sebagai validator isi/materi.

hasil perolehan uji validasi menunjukkan perolehan sebesar $89 \%$ jika di konversi yang berarti nilai 100 (sempurna) selanjutnya hasil tersebut dikonversikan pada tingkat kevalidan produk sebagaimana yang disajikan pada bab III maka hasil tersebut mendapat kriteria sangat valid.

Saran dan komentar dari hasil uji validasi

isi/materi selanjutnya dijadikan bahan untuk merevisi produk pengembangan sebelum diujicobakan kepada siswa pengguna.

\section{Data Uji Validasi Ahli Media Pembelajaran}

Uji ahli media bertujuan untuk mengevaluasi materi dan desain produk serta kualitas produk model pembelajaran yang sudah dikembangkan. Harapannya, model pembelajaran yang sudah dikembangkan oleh peneliti nantinya memiliki daya tarik tersendiri bagi siswa sehingga mampu mendorong aktivitas dan perolehan hasil belajar yang maksimal. Ahli media pembelajaran yang dipercayakan sebagai validator model pembelajaran yaitu Bapak Dr. Hadi Gunawan Sakti, M.Pd. Hasil uji validasi ahli media dapat dilihat pada tabel di bawah ini.

Berdasarkan tabel di atas hasil perolehan uji validasi terhadap model pembelajaran yang dikembangkan menunjukkan hasil presentase sebesar 91\% Setelah dikonversi pada tabel tingkat kelayakan, produk tersebut termasuk dalam kategori cukup valid. Berdasarkan kriteria tersebut produk yang sudah dikembangkan dapat digunakan dengan revisi kecil.

Namun demikian beberapa catatan berupa saran dan komentar dari validator ahli media terhadap keseluruhan model pembelajaran dapat dilihat pada tabel di bawah ini.

\section{Tabel Saran dan Komentar Uji Validasi Ahli Media}

\begin{tabular}{|l|l|}
\hline No & \multicolumn{2}{|c|}{ Kritik dan Saran } \\
\hline & $\begin{array}{l}\text { Kesesuaian materi dengan ilustrasi } \\
\text { gambar perlu diperbanyak lagi, agar } \\
\text { tingkat pemahaman semakin bagus. }\end{array}$ \\
\hline & Tampilan warna perlu dioptimalkan \\
\hline & $\begin{array}{l}\text { Penyajian alur permainan perlu } \\
\text { dijelaskan dengan mind map atau } \\
\text { ilustrasi gambar }\end{array}$ \\
\hline & Berikan rangkuman setiap sub tema \\
\hline & $\begin{array}{l}\text { Sajian evaluasi diperbanyak lagi } \\
\text { sekaligus referensi }\end{array}$ \\
\hline
\end{tabular}

Saran dan komentar dari hasil uji validasi ahli media selanjutnya dijadikan bahan untuk merevisi produk pengembangan sebelum diujicobakan kepada siswa pengguna.

\section{Uji Coba Kelompok Kecil}

Uji coba kelompok kecil. Subjek uji coba sebanyak enam orang siswa kelas XI SMAN 1 Masbagik. Keenam orang tersebut terdiri dari dua orang siswa berkemampuan baik, dua orang siswa berkemampuan sedang dan dua orang siswa berkemampuan rendah. Tujuan uji coba perorangan adalah untuk mengetahui kemenarikan produk model pembelajaran.

Sama halnya dengan uji coba kelompok kecil, proses uji coba berlangsung selama kurang lebih 60 menit setelah jam istirahat dan peneliti tetap berada disekitar siswa agar dapat membimbing dalam melakukan penilaian agar mendapatkan hasil seperti yang diharapkan. Berikut ini disajikan hasil uji coba kelompok kecil pada tabel di bawah ini.

Berdasarkan tabel di atas, perolehan rata - rata dari uji coba kelompok kecil sebesar 92,92\%. Setelah dikonversi presentase tersebut termasuk dalam kategori sangat menarik. Beberapa catatan berupa komentar dan saran yang dirangkum dari lembar angket kemenarikan disajikan pada tabel di bawah ini.

Tabel 5.6 Saran dan Komentar Uji Coba Kelompok Kecil

\begin{tabular}{|c|l|}
\hline No & \multicolumn{1}{|c|}{ Saran dan Komentar } \\
\hline $\mathbf{1}$ & $\begin{array}{l}\text { Dengan adanya sistem model } \\
\text { pembelajaran, siswa jadi mengerti. }\end{array}$ \\
\hline $\mathbf{2}$ & $\begin{array}{l}\text { Model pembelajaran ini membuat saya } \\
\text { pintar dan berguna. }\end{array}$ \\
\hline $\mathbf{3}$ & Sangat jelas dan ringkas \\
\hline
\end{tabular}

Saran dan komentar dari hasil uji coba kelompok selanjutnya dijadikan bahan untuk merevisi produk pengembangan.

\section{Hasil Uji Lapangan dengan Pre-Test Dan Pos-Test}

Uji coba lapangan dilakukan dengan melibatkan 30 orang siswa kelas XI (sos I) SMAN 1 masbagik. Uji coba lapangan dilakukan dengan dua cara yaitu proses Pre-test (sebelum menggunakan produk) dan Pos-test (setelah menggunakan prouk model pembelajaran) uji ini dilakukan untuk mengetahui perbedaan tingkat hasil belajar siswa.

a. Uji Keterlaksanaan Model pembelajaran

1) Deskripsi Hasil Belajar

Hasil belajar siswa diambil dari penilaian pada 
proses pembelajaran siswa di kelas sebelum dan sesudah menggunakan produk model pembelajaran my trip my adventure.

a) Pretest Hasil Belajar Siswa

Tabel 5.7 Persentase Hasil Belajar Siswa Pretest

\begin{tabular}{|c|c|c|c|c|c|}
\hline No & $\begin{array}{c}\text { Rentang } \\
\text { Nilai }\end{array}$ & Frekuensi & Persentase & \multicolumn{2}{|c|}{ Kriteria } \\
\cline { 4 - 6 } & & & & Tuntas & $\begin{array}{c}\text { Tidak } \\
\text { Tuntas }\end{array}$ \\
\hline 1 & $50-60$ & 10 & 33.33 & & 10 \\
\hline 2 & $60-70$ & 13 & 43.33 & & 13 \\
\hline 3 & $70-80$ & 7 & 23.33 & 7 & \\
\hline 4 & $80-90$ & & & & \\
\hline 5 & $90-100$ & & & & \\
\hline \multicolumn{2}{|c|}{ Jumlah } & 30 & & & $\mathbf{2 3}$ \\
\hline \multicolumn{2}{|c|}{ Prosentase } & & $99.99 \%$ & $\mathbf{2 3 . 3 3 \%}$ & $\mathbf{7 6 . 7}$ \\
\hline
\end{tabular}

Hasil belajar sebelum menggunakan model pembelajaran menunjukkan bahwa hasil belajar sebelum menggunakan model pembelajaran adalah sebanyak 23 siswa atau $76.7 \%$ mengalami tidak tuntas dalam proses pembelajaran, dan hanya 7 orang siswa saja yang mengalami tuntas belajar atau sebesar $23 \%$ dari total 30 siswa yang mengikuti proses pembelajaran di kelas XI (sos I).

b) Postest Hasil Belajar Siswa

Hasil belajar setelah menggunakan model pembelajaran menunjukkan bahwa hasil belajar setelah menggunakan model pembelajaran adalah sebanyak 9 orang siswa berada pada rentang nilai hasil belajar $80-90$ atau $30.00 \%$ dan di anggap tuntas dalam proses pembelajaran, sedangkan dari rentang nilai 90-100 sebanyak 21 orang siswa tuntas dalam proses pembelajaran setelah menggunakan model pembelajaran dengan nilai yang sangat memuaskan atau sebesar $70 \%$ dari total 30 siswa yang mengikuti proses pembelajaran di kelas XI (sos I).

Tabel 5.8 Persentase Hasil Belajar Siswa Postest

\begin{tabular}{|c|c|c|c|c|c|}
\hline No & $\begin{array}{c}\text { Rentang } \\
\text { Nilai }\end{array}$ & Frekuensi & Persentase & \multicolumn{2}{|c|}{ Kriteria } \\
\cline { 5 - 6 } & & & & Tuntas & $\begin{array}{c}\text { Tidak } \\
\text { Tuntas }\end{array}$ \\
\hline 1 & $50-60$ & & & & \\
\hline 2 & $60-70$ & & & & \\
\hline 3 & $70-80$ & & & & \\
\hline 4 & $80-90$ & 9 & 30.00 & 9 & \\
\hline 5 & $90-100$ & 21 & 70.00 & 21 & \\
\hline \multicolumn{2}{|c|}{ Jumlah } & $\mathbf{3 0}$ & & $\mathbf{3 0}$ & \\
\hline \multicolumn{2}{|c|}{ Prosentase } & & $\mathbf{1 0 0} \%$ & $\mathbf{1 0 0 \%}$ & \\
\hline
\end{tabular}

Dari pemaparan hasil belajar di atas

menunjukkan tabel distribusi hasil belajar siswa diatas menunjukkan bahwa siswa mencapai ketuntasan belajar terbanyak dicapai dengan rentang skor 90 - 100 dengan presentase sebesar $70 \%$. Peringkat ketuntasan kedua dicapai oleh siswa pada rentang skor 80 - 90 dengan presentase sebesar $30 \%$. Ini menunjukkan bahwa produk model pembelajaran yang di kembangkan dapat meningkatkan hasil belajar pada siswa kelas XI (sos I) SMAN 1 Masbagik.

\section{KESIMPULAN}

1. Dari hasil validasi ahli materi ekonomi dan ahli media pembelajaran menyatakan produk model pembelajaran ini layak diterapkan.

2. Dari hasil angket yang diberikan kepada siswa dan guru bahwa produk model pembelajaran my trip my adventure (MTMA) ini mendapat apresiasi yang positif

3. Dari Hasil uji coba lapangan yang telah dilakukan kepada siswa SMAN 1 Masbagik menunjukkan bahwa produk model pembelajaran sangat efektif digunakan pada materi kurs valuta asing.

\section{DAFTAR PUSTAKA}

Affan, A, 2011, Penerapan Pembelajaran kooperatif Model Quiz-Quiz Trade dan Team Game Tournament untuk Meningkatkan Hasil Belajar, Keaktifan Belajar dan Self Esteem. Program Pascasarjana Universitas Negeri Malang.

Ardhana, Wayan. 2002. Konsep Penelitian Pengembangan dalam Bidang Pendidikan dan Pembelajaran. Makalah disajikan dalam Lokakarya Nasional Angkatan II, Pusat Penelitian Pendidikan, Malang, 22-24. 
Arens, Richad. 2008. Learning to Teach, belajar untuk mengajar. Yogyakarta: Pustaka Pelajar.

Arikunto, Suharsimi. 2002. Prosedur Penelitian suatu pendekatan praktek. Jakarta : PT. Rineka Cipta.

Borg. W.R., dan Gall, M.D., 1983, Educational Research: An Introductio, New York Longman.

Creswell, Jhon W. 2012. Research Design, Pendekatan Kuantitatif, Kualitatif dan Mixed. Yogyakarta: Pustaka Pelajar.

Darmadi, H. 2011. Metode penelitian pendidikan. Bandung: Alfabeta.

Departemen Pendidikan Nasional. Bimtek KTSP 2008.(Online), http://www.depdiknas.go.id), diakses 25 November 2015.

Desminta, 2005, Psikologi Perkembangan, Bandung - PT. Remaja Rosdakarya.

Djamarah, Syaiful Bahri. 2002. Psikologi Belajar. Jakarta: PT Rineka Cipta.

Hamalik, Oemar. 2010. Proses Belajar Mengajar. Jakarta: Bumi Aksara

Indrawati, A., 2009, Pengembangan Model Pembelajaran yang Berorientasi Jiwa Kewirausahaan pada Pendidikan Anak Usia Dini, Disertasi, Program Pascasarjana Universitas Negeri Malang.

Masri Muhammad,Dkk. 1997 Materi Latihan Kerja Guru Pendidikan Pancasila dan Kewarganegaraan. Jakarta: Departemen Pendidikan dan Kebudayaan

Mbulu, Joseph dan Suhartono. 2004. Pengembangan Model pembelajaran. Malang: Elang Mas.
Moleong, Lexy J. 2012. Metodologi Penelitian Kualitatif. Bandung: Remaja Rosda karya.

Muhaimin, 2009. Modul Wawasan Pengembangan Model pembelajaran bab V Malang: LKP2-I

Nusa, P. 2012. Research \& Development: Penelitian dan Pengembangan Suatu Pengantar. Jakarta: PT Raja Grafindo Persada.

Putri, R, 2014, Pengembangan Model Pembelajaran The Money Adventure, Program Pascasarjana Universitas Negeri Malang.

Rusman, 2012, Model-model Pembelajaran mengembangkan profesionalisme guru, Jakarta - PT. Raja Grafindo Persada.

Stančić, H, 2007, Simulation Models in Education. INFuture2007

Sudjana, Nana dan Rivai Ahmad. 2005. Media Pengajaran. Bandung: Sinar Baru Algensindo.

Sugiyono. 2009. Metode Penelitian Pendidikan (Pendekatan Kuantitatif, Kualitatif, dan $R$ $\& D)$. Bandung: Alfabeta.

Sugiyono, 2011, Statistika untuk Penelitian, Bandung - CV Alfabeta.

Thobroni, Muhammad \& Arif Mustofa. 2011. Belajar \& Pembelajaran: Pengembangan Wacana dan Praktik Pembelajaran dalam Pembangunan Nasional. Jogjakarta: Ar-Ruzz Media. Tahun-2003-Sisdiknas.pdf), diakses 7 februari 2018.

Wahyono, Hari. 2013. Revitalisasi Pendidikan Ekonomi, Perilaku Berkarakter dan Permasalahan Ekonomi. Malang: Materi seminar pendidikan nasional. 